\title{
Polymorphism of the complement 5 gene is associated with large artery atherosclerosis stroke in Chinese patients
}

\author{
0 polimorfismo do gene $\mathrm{C} 5$ do complemento está associado a acidentes vasculares \\ cerebrais de grandes artérias com aterosclerose em pacientes chineses
}

Hui Wu'1, Yingfeng Weng', Lan Zheng', Huanyin Li', Qi Gong', Yi Fu'², Jing Zhao'

\begin{abstract}
The complement system has been confirmed to play an increasingly important role in ischemic stroke (IS). This study aimed to determine whether the single-nucleotide polymorphism of the complement 5 (C5) gene independently influences the occurrence, severity, and long-term outcome of IS in Chinese patients. Methods: C5 rs 17611 genetic variants were investigated in 494 IS patients and 330 control individuals. Ischemic stroke was classified into subtypes and patients were assessed 90 days post-stroke with the modified Rankin Scale to determine stroke outcome. Results: The presence of C5 polymorphism was associated with the incidence of large artery atherosclerosis ( $L A A)$-subtype IS ( $n=200 ; p=0.031)$, which even persisted after adjustment for covariates $(O R=1.518$; $95 \% \mathrm{Cl}=1.093-2.018 ; \mathrm{p}=0.013)$. However, no association was found between genotypes and the severity and outcome of stroke ( $p=0.978 ; p=0.296$ ). Conclusions: The C5 polymorphism might contribute to the risk of LAA-subtype IS independently of other known risk predictors.
\end{abstract}

Keywords: genes; stroke.

\section{RESUMO}

Já se confirmou que o sistema do complemento exerce um papel cada vez mais importante nos acidentes vasculares cerebrais isquêmicos. Este estudo teve o objetivo de determinar se o polimorfismo de nucleotídeo único (SNP) do gene codificador do componente 5 (C5) influencia de forma independente a ocorrência, a severidade e o desfecho em longo prazo do acidente vascular cerebral isquêmico (AVCI) em pacientes chineses. Métodos: Variantes genéticas rs 17611 do C5 foram investigadas em 494 pacientes com AVCl e em 330 indivíduos controles. 0 AVCI foi classificado em subtipos e os pacientes foram avaliados 90 dias após o acidente vascular, através da Escala Modificada de Rankin (mRS), para determinação do desfecho do acidente. Resultados: A presença de polimorfismo do C5 foi associada à incidência de AVCl do subtipo com aterosclerose de grandes artérias (AGA) $(n=200 ; p=0,031)$, que persistiu mesmo após os ajustes de covariáveis (RP = 1,518; 95\% IC = 1,093-2,018; $p=0,013)$. Entretanto, nenhuma associação foi observada entre os genótipos e a severidade ou o desfecho do acidente vascular ( $p=0,978 ; p=0,296$ ). Conclusões: 0 polimorfismo do C5 pode contribuir para o risco de AVCl do tipo com AGA, independentemente de outros riscos preditores conhecidos.

Palavras-chave: genes; acidente vascular cerebral.

Stroke is the major cause of serious, permanent disability requiring institutional long-term care and is the second most common cause of mortality worldwide. There are 2.5 million stroke attacks and 1 million stroke-related deaths in China annually ${ }^{1}$. In addition to age and sex, other risk factors include hypertension, diabetes mellitus, smoking, and hypercholesterolemia. However, the prevalence of these conditions is not enough to explain the rising incidence of ischemic stroke (IS).
Atherosclerosis is the major pathological mechanism of IS, and the inflammatory response is known to play a key role in the development of atherosclerosis. The inflammatory response has been associated with the occurrence of atherosclerosis ${ }^{2}$ in the carotid arteries or the aorta ${ }^{3}$. Interactions among lipoproteins, macrophages, T-lymphocytes, and endothelial cells of the vessel wall are responsible for the development of atherosclerotic lesions ${ }^{4}$. Humoral inflammatory

${ }^{1}$ Minhang District Central Hospital, Department of Neurology, Shanghai, China;

2Shanghai Jiao Tong University School of Medicine, Ruijin Hospital.

Correspondence: Jing Zhao; 170 Road, Shanghai, 201100, China; E-mail: zhaojingssmu@163.com

Conflict of interest: There is no conflict of interest to declare.

Support: This work was supported by the National Natural Science Foundation of China (81572232), Shanghai Natural Science Foundation (13ZR1436600), Shanghai Health Bureau and the leading talents (20124266), Minhang District Natural Science Research Project (2015MHZ038)

Received 08 April 2016; Received oin final form 19 June 2016; Accepted 26 July 2016. 
mediators-in particular the complement system-have previously been shown to be associated with the formation process of atherogenesis ${ }^{5}$. Greisenegger et al. ${ }^{6}$ investigated 49 single-nucleotide polymorphism (SNP)s in 34 genes and evaluated their contribution to the risk of acute ischemic stroke and transient ischemic attack in a large cohort of consecutive patients and controls individually. At last they found evidence for an association of the complement 5 (C5) rs 17611 polymorphism with the risk for IS and transient ischemic attack in Austrian patients ${ }^{6}$. Therefore, the aim of this study was to evaluate the possible associations of the C5 rs17611 with the susceptibility, severity, and 90-day outcome of IS in Chinese patients.

\section{METHODS}

\section{Patients and control individuals}

Patients with IS admitted to Shanghai Minhang District Central Hospital from 2008 to 2012 were recruited. Individuals in the control group were patients with chronic disease(s) recruited from the same hospital in the physical examination center. They were confirmed free of IS on cranial CT/MRI and stroke or/and myocardial infarction history.

The study was approved by the Institutional Ethical Committee of Shanghai Minhang District Central Hospital. Each participant or their legal representatives signed an informed consent form.

The diagnosis was made based on MRI within two days after onset. All patients received a complete physical examination with a precise record of their medical history. All patients received standardized treatment according to guidelines for the early management of adults who experience IS ${ }^{7}$. Common and internal carotid arteries were investigated for the presence of plaques. Ultrasonography was performed with MyLab90 with a 3-9 MHz linear array transducer. Atherosclerotic plaque was defined as a focal structure that encroaches into the arterial lumen of at least $0.5 \mathrm{~mm}$ or $50 \%$ of the surrounding intima media thickness (IMT) or demonstrates a thickness of $\geq 1.5 \mathrm{~mm}$ as measured from the media-adventitia interface to the intima-arterial lumen interface.

\section{Clinical examination}

A detailed history was obtained, and a complete clinical evaluation was performed for each patient. All patients with IS were divided into subtypes: large artery atherosclerosis (LAA), small artery occlusion (SAO), and cardioembolism (CE), and other strokes with other or undetermined etiology using the Trial of Org 10172 in Acute Stroke Treatment (TOAST) classification ${ }^{8}$. Subtype analysis was limited to LAA $(\mathrm{n}=200)$, SAO $(\mathrm{n}=165)$, and CE $(n=82)$ because of the small sample sizes of other subtypes $(n=47)$.
On the first day of admission, disease severity was measured by using the National Institutes of Health Stroke Severity Scale (NIHSS) ${ }^{9}$, and mild stroke was defined as a NIHSS of 6 or less points and severe stroke as a NIHSS of 7 or higher.

Post-stroke disability was evaluated using the modified Rankin Scale (mRS) ${ }^{10} 90$ days after the acute stroke. Good recovery was defined as an mRS of 1 or less points and poor recovery as an mRS of 2 or higher; $0-1$ indicates minimal or no disability.

\section{Genotype determination}

Genomic DNA was extracted from $200 \mu$ l of EDTA-treated blood by using a UNIQ-10 Genome Extraction Kit Genomic DNA purification kit (TaKaRa Biotechnology, Dalian) according to the manufacturer's instructions. Genotypes were determined by PCR-LDR assay. Genomic DNA was PCR amplified and designed using the web-based version of the Primer 3.0 program (http://frodo.wi.mit.edu/primer3/). The rs17611 SNP was amplified by the following pair of primers: forward, AACTTCCAGAAAACAGTTGCAG; reverse, TGCTACCATTTAAGTCCTGGGTA. The PCR amplification was performed in a $20-\mu \mathrm{l}$ reaction volume containing $1 \mu \mathrm{l}$ of 50ng genomic DNA, $2 \mu \mathrm{l}$ of $10 \times$ PCR amplification buffer, $2 \mu \mathrm{l}$ of $2.5 \mathrm{mM}$ dNTP mixture, $0.2 \mu \mathrm{l}$ of $50 \mathrm{pmol} / \mu \mathrm{l}$ of each primer, and $0.3 \mu \mathrm{l}$ of $1 \mathrm{U}$ Taq DNA polymerase (TaKaRa Biotechnology, Dalian). The conditions used for the PCR amplification included initial denaturation of $2 \mathrm{~min}$ at $95^{\circ} \mathrm{C}$, followed by 35 cycles of denaturation at $94^{\circ} \mathrm{C}$ for 30 s, annealing at $56^{\circ} \mathrm{C}$ for $1 \mathrm{~min} 30$, and extension at $72^{\circ} \mathrm{C}$ for $1 \mathrm{~min}$ followed by a final extension at $72^{\circ} \mathrm{C}$ for 10 minutes. The purified PCR products were then sequenced on an $\mathrm{ABI} 3730 \mathrm{XL}$ sequencer (America ABI Company).

The ligation detection reaction for each subject was carried out in a final volume of $10 \mu \mathrm{l}$ containing $1 \mu \mathrm{l} 100 \mathrm{ng} / \mu \mathrm{l}$ PCR product, $1 \mu \mathrm{l}$ of $10 \times$ buffer, $1 \mu \mathrm{l}$ of $12.5 \mathrm{pmol} / \mu \mathrm{l}$ of each probe mix, and $0.05 \mu \mathrm{l} 2 \mathrm{U}$ Taq DNA ligase (NEB Biotechnology (Beijing)). A total of ligase detection reaction was performed at $95^{\circ} \mathrm{C}$ for 2 min using 30 cycles at $94^{\circ} \mathrm{C}$ for $15 \mathrm{~s}$ and $50^{\circ} \mathrm{C}$ for 25 seconds. The fluorescent products of ligase detection reaction were differentiated by $\mathrm{ABI} 3730 \mathrm{XL}$ sequencer (ABI).

\section{Statistical analysis}

All statistical tests were performed with SPSS19.0 software (SPSS, Inc., Chicago, IL, USA). Demographic data, clinical characteristics, severity on the NIHSS at admission, and mRS outcome 90 days after discharge were compared by using t-tests or $\chi^{2}$ tests. Allele frequencies were calculated using the following equation: allele frequency $=$ (number of homozygotes $\times 2+$ number of heterozygotes) $\times 0.5 \times 1 / \mathrm{n}$. The $\chi^{2}$ test was used to determine whether the genotype distributions were in Hardy-Weinberg equilibrium. Non-parametric analyses were used if the variance was high. Logistic regression models were used for calculating odds ratios (95\% 
confidence interval) and corresponding p-values, controlling for the presence of risk factors as covariates. A p-value $<0.05$ was taken to indicate statistical significance.

\section{RESULTS}

The IS group comprised 300 men and 194 women with a mean age of $69.75 \pm 11.32$ years. The control group comprised 183 men and 147 women with a mean age of $68.87 \pm 10.02$ years. There were no statistically significant differences in age $(\mathrm{p}=0.250)$ or sex $(\mathrm{p}=0.603)$ between both groups. Conventional cerebrovascular risk factors in the case group included hypertension, $\mathrm{n}=374$ (75.7\%); diabetes mellitus, $\mathrm{n}=168$ (34.0\%); hypercholesterolemia, $\mathrm{n}=164$ (33.2\%); smoking, $\mathrm{n}=202$ (40.9\%); and atherosclerotic plaque, $\mathrm{n}=315(63.8 \%)$. And these risk factors in the control group included hypertension, $\mathrm{n}=199$ (60.3\%); diabetes mellitus, $\mathrm{n}=56$ (17.0\%); hypercholesterolemia, $\mathrm{n}=77$ (23.3\%); smoking, $\mathrm{n}=88$ (26.7\%); and atherosclerotic plaque, $\mathrm{n}=147$ (44.5\%) (Table 1). These risk factors were controlled in both groups.

\section{Stroke occurrence}

Genetic analysis of the C5 rs17611 polymorphism was performed for all 494 patients and 330 controls. The genotype and allele frequency in the IS patients and control subjects are presented in Table 2. We found no statistical difference of the C5 rs17611 gene polymorphism between groups $(p=0.541)$. However, when patients were classified into subtypes, we found a statistical difference between LAA-subtype and control individuals in the GG genotype distribution $(p=0.031)$ and $G$ allele $(p=0.016)$. We calculated the adjusted odds ratios (OR) using multiple logistic regression analysis with adjustments for the traditional risk factors, including hypertension, diabetes mellitus, hypercholesterolemia, and smoking in Table 3. The results suggested that the $\mathrm{G}$ allele was an independent risk factor for LAA-subtype IS $(\mathrm{OR}=1.518 ; 95 \% \mathrm{CI}=1.093-2.018 ; \mathrm{p}=0.013)$.

Table 1. Baseline characteristics of patients and controls.

\begin{tabular}{lccc}
\hline Characteristic & Controls $(n=330)$ & Patients $(n=494)$ & $p$ \\
\hline Age (year) & $68.87 \pm 10.02$ & $69.75 \pm 11.32$ & 0.250 \\
Gender M/F & $183 / 147$ & $300 / 194$ & 0.603 \\
Hypertension & $199(60.3 \%)$ & $374(75.7 \%)$ & $0.000^{\star}$ \\
Diabetes mellitus & $56(17.0 \%)$ & $168(34.0 \%)$ & $0.000^{\star}$ \\
Hypercholesterolemia & $77(23.3 \%)$ & $164(33.2 \%)$ & $0.002^{\star}$ \\
Smoking & $88(26.7 \%)$ & $202(40.9 \%)$ & $0.000 *$ \\
Atherosclerotic plaque & $147(44.5 \%)$ & $315(63.8 \%)$ & $0.000 *$ \\
\hline
\end{tabular}

M: masculine; F: feminine; ${ }^{*} p<0.05$ is considered statistically significant.

Table 2. Genotypes and allele frequencies of patients and controls.

\begin{tabular}{|c|c|c|c|c|c|}
\hline \multirow[b]{2}{*}{ rs17611 } & \multirow{2}{*}{$\begin{array}{l}\text { Controls } \\
(n=330)\end{array}$} & \multirow{2}{*}{$\begin{array}{l}\text { Total (\%) } \\
\text { Patients } \\
(n=494)\end{array}$} & \multicolumn{3}{|c|}{ TOAST subtype (\%) } \\
\hline & & & $\begin{array}{c}\text { LAA } \\
(n=200)\end{array}$ & $\begin{array}{c}\text { SAO } \\
(n=165)\end{array}$ & $\begin{array}{c}C E \\
(n=82)\end{array}$ \\
\hline \multicolumn{6}{|l|}{ Genotype } \\
\hline $\mathrm{AA}$ & 230(69.7) & $327(66.2)$ & $117(58.5)$ & $119(72.1)$ & $58(70.7)$ \\
\hline$A G$ & $91(27.6)$ & 154(31.2) & 76(38) & $44(26.7)$ & $20(24.4)$ \\
\hline$G G$ & $9(2.7)$ & $13(2.6)$ & $7(3.5)$ & $2(1.2)$ & $4(4.9)$ \\
\hline$P$ & & 0.541 & $0.031 *$ & 0.532 & 0.543 \\
\hline \multicolumn{6}{|l|}{ Allele } \\
\hline A & $551(83.5)$ & 808(81.8) & $310(77.5)$ & 282(85.5) & $136(82.9$ \\
\hline G & 109(16.5) & 180(18.2) & $90(22.5)$ & $48(14.5)$ & $28(17.1)$ \\
\hline P & & 0.373 & $0.016^{*}$ & 0.424 & 0.864 \\
\hline
\end{tabular}

TOAST: Trial of Org 10172 in acute stroke treatment; LAA: large artery atherosclerosis, SAO: small artery occlusion, CE: cardioembolism. ${ }^{\star} \mathrm{p}<0.05$ is considered statistically significant.

Table 3. Logistic regression analysis of the C5 rs17611 polymorphisms with risk of IS of LAA subtype, adjusted by confounding factors.

\begin{tabular}{|c|c|c|c|c|c|c|c|c|}
\hline \multirow{2}{*}{ Variable } & \multirow{2}{*}{ B } & \multirow{2}{*}{ S.E, } & \multirow{2}{*}{ Wals } & \multirow{2}{*}{$d f$} & \multirow{2}{*}{ Sig. } & \multirow{2}{*}{ OR } & \multicolumn{2}{|c|}{$95 \% \mathrm{Cl}$} \\
\hline & & & & & & & Lower limit & Upper limit \\
\hline Hypertension & .688 & .148 & 21.646 & 1 & .000 & 1.989 & 1.489 & 2.657 \\
\hline Diabetes mellitus & .786 & .155 & 25.737 & 1 & .000 & 2.194 & 1.619 & 2.971 \\
\hline Hypercholesterolemia & .462 & .149 & 9.605 & 1 & .002 & 1.587 & 1.185 & 2.126 \\
\hline Smoking & .804 & .140 & 32.861 & 1 & .000 & 2.234 & 1.697 & 2.941 \\
\hline rs17611 & .417 & .168 & 6.212 & 1 & $.013^{\star}$ & 1.518 & 1.093 & 2.108 \\
\hline
\end{tabular}

B: beta; SE: Standard error; $\mathrm{dF}$ : degree of freedom; OR: odds ratio; ${ }^{\star} \mathrm{p}<0.05$ is considered statistically significant. 


\section{Association of the C5 rs17611 genotype with the severity and outcome of IS}

On the first day of admission, severity was assessed by using the NIHSS. A total of 494 patients were classified into the mild $(\mathrm{n}=382)$ and severe groups $(\mathrm{n}=112)$. We did not find any association between gene polymorphism and stroke severity in the whole group $(\mathrm{p}=0.978)$ or in subtypes (LAA: $\mathrm{p}=0.765$; SAO: $\mathrm{p}=0.767 ; \mathrm{CE}: \mathrm{p}=0.479$ ) (Table 4). We then stratified all patients according to the different outcomes (Table 5). Of the 494 stroke patients, 308 (62.3\%) were assessed 90 days after the acute event; eight patients (1.6\%) died, 11 patients (2.2\%) had a recurrent IS, and 167 patients (33.8\%) were lost to follow-up. Of these 308 patients, 193 were classified as having good recovery and 115 as having poor recovery. We obtained no significant correlation between the genotype and long-term prognosis in total patients $(p=0.296)$ or in the subtypes (LAA: $p=0.826$; SAO: $p=0.567 ;$ CE: $p=0.154)$.

\section{DISCUSSION}

Our study determined the distribution of the C5 rs1761 polymorphism and its association with occurrence, severity, and outcome of acute IS in Chinese patients. Although we did not find a correlation between the genotype and the occurrence of IS in the overall distribution, to our surprise, when we analyzed the cases subtypes, we found that the G allele and GG genotype in the C5 rs17611 polymorphism was significantly associated with the LAA stroke subtype $(\mathrm{p}=$ 0.016; $\mathrm{p}=0.031$ ), which persisted even after adjustment for covariates $(\mathrm{OR}=1.518 ; 95 \% \mathrm{CI}=1.093-2.018 ; \mathrm{p}=0.013)$. It may be that the main pathogenesis of the LAA subtype is atherosclerosis, and the inflammatory response was critical to atherogenesis ${ }^{2}$. Since inflammation may aggravate the severity of acute stroke, and the outcome will be worse as well, we analyzed the relationship between the presence of C5 rs 17611 genotype and acute severity as well as long-term outcome of stroke, but no statistical difference was found.

The complement system consists of a set of plasma proteins involved in the inflammatory response. In atheromas, complement system elements such as various complement receptors, complement activation products, and regulatory proteins have been found ${ }^{11,12}$. C5 plays an important role in the immune cascade. Under the action of C5 invertase, C5 is decomposed to produce two kinds of product: $\mathrm{C} 5 \mathrm{a}$ and C5b. $\mathrm{C} 5 \mathrm{~b}$ interacts with other complement proteins to form the membrane attack complex, which consists of a lytic pore that leaks the intracellular contents. The smaller molecule, C5a, promotes pro-inflammatory reactions and is closely linked to chemokine generation and adhesion molecule production by endothelial cells ${ }^{12}$. Vascular endothelial cell damage and cholesterol deposition form the artery atheromatous plaque. There is a great deal of strong evidence to support a close relationship between the complement system and the progression of atherothrombotic vascular disease, including IS. Signs of complement activation have been detected in atherosclerotic arterial walls ${ }^{12}$. Plasma C 3 and C3a levels are associated with large-vessel disease stroke ${ }^{13}$, and different complement components play different roles in the course of stroke ${ }^{14}$. Szeplaki et al. found that C5b-9 levels exhibited significant positive correlation with the severity of neurological deficit as well as the level of functional disability ${ }^{15}$.

A few functional studies of $\mathrm{C} 5$ or $\mathrm{C} 5$ a have been reported. Hillebrandt et al. thought that $\mathrm{C} 5$ had a causal role in liver fibrogenesis across species ${ }^{16}$. Liu et al. obtained the result that C5a may be one of the factors contributing to age-related macular degeneration ${ }^{17}$.

Table 4. Genotype frequency distribution and association with severity measured by NIHSS on the first day [Mild $(\leq 6)$; Severe $(\geq 7)]$.

\begin{tabular}{|c|c|c|c|c|c|c|c|c|}
\hline \multirow{3}{*}{$\begin{array}{l}\text { rs17611 } \\
\text { AA }\end{array}$} & \multirow{2}{*}{\multicolumn{2}{|c|}{$\begin{array}{c}\text { TOTAL (\%) } \\
\text { IS }(n=494)\end{array}$}} & \multicolumn{6}{|c|}{ TOAST subtype (\%) } \\
\hline & & & \multicolumn{2}{|c|}{$\operatorname{LAA}(n=200)$} & \multicolumn{2}{|c|}{$S \tilde{O} O(n=165)$} & \multicolumn{2}{|c|}{$C E(n=82)$} \\
\hline & $252(66.0)$ & $75(67.0)$ & $94(57.3)$ & $23(63.9)$ & $87(72.5)$ & $32(71.1)$ & $43(74.1)$ & $15(62.5)$ \\
\hline$A G$ & $120(31.4)$ & $34(30.4)$ & 64(39.0) & 12(33.3) & $32(26.7)$ & $12(26.7)$ & $12(20.7)$ & $8(33.3)$ \\
\hline GG & $10(2.6 \%)$ & $3(2.6 \%)$ & $6(3.7 \%)$ & $1(2.8 \%))$ & $1(0.8 \%)$ & $1(2.2 \%)$ & $3(5.2 \%)$ & $1(4.2 \%)$ \\
\hline$\chi^{2}$ & \multicolumn{2}{|c|}{0.045} & \multicolumn{2}{|c|}{0.535} & \multicolumn{2}{|c|}{0.530} & \multicolumn{2}{|c|}{1.473} \\
\hline $\mathrm{p}$ & \multicolumn{2}{|c|}{0.978} & \multicolumn{2}{|c|}{0.765} & \multicolumn{2}{|c|}{0.767} & \multicolumn{2}{|c|}{0.479} \\
\hline
\end{tabular}

TOAST: Trial of Org 10172 in acute stroke treatment; LAA: large artery atherosclerosis; SAO: small artery occlusion; CE: cardioembolism; NIHSS: National Institutes of Health Stroke Severity Scale.

Table 5. Genotype frequency distribution and association with 90 functional outcomes [Good $(\leq 1)$; Poor $(\geq 2)]$.

\begin{tabular}{|c|c|c|c|c|c|c|c|c|}
\hline \multirow{3}{*}{$\begin{array}{l}\text { rs17611 } \\
\text { AA }\end{array}$} & \multirow{2}{*}{\multicolumn{2}{|c|}{$\begin{array}{c}\text { Total large artery } \\
\text { atherosclerosis }(\%) \\
\text { IS }(n=308)\end{array}$}} & \multicolumn{6}{|c|}{ TOAST subtype (5) } \\
\hline & & & \multicolumn{2}{|c|}{$\operatorname{LAA}(n=130)$} & \multicolumn{2}{|c|}{ SÃO $(n=102)$} & \multicolumn{2}{|c|}{ CE $(n=47)$} \\
\hline & $118(61.1)$ & $76(66.1)$ & $44(56.4)$ & $31(59.6)$ & $44(63.8)$ & $24(72.7)$ & $16(64.0)$ & $16(72.7)$ \\
\hline$A G$ & 72(37.3) & $35(30.4)$ & $32(41.0)$ & $19(36.5)$ & $24(34.8)$ & $9(27.3)$ & $9(36.0)$ & $4(18.2)$ \\
\hline GG & $3(1.6)$ & $4(3.5)$ & $2(2.6)$ & 2(3.8) & $1(1.4)$ & $0(0.0)$ & $0(0.0)$ & $2(9.1)$ \\
\hline$x^{2}$ & \multicolumn{2}{|c|}{2.433} & \multicolumn{2}{|c|}{0.382} & \multicolumn{2}{|c|}{1.136} & \multicolumn{2}{|c|}{3.747} \\
\hline$p$ & \multicolumn{2}{|c|}{0.296} & \multicolumn{2}{|c|}{0.826} & \multicolumn{2}{|c|}{0.567} & \multicolumn{2}{|c|}{0.154} \\
\hline
\end{tabular}


The C5 gene is located in 9q33-q34, which encodes the fifth component of complement. C5 rs17611 polymorphism is associated with many diseases. Woehrl et al. found that the C5 rs17611 is associated with unfavorable disease outcome in patients with bacterial meningitis ${ }^{18}$. Recently, Giles et al. showed that individuals homozygously (GG) expressing the C5 rs17611 allele exhibit increased C5a and decreased C5 in plasma ${ }^{19}$. In this study, they explored the functional consequences of an SNP (rs17611) encoding a V802I polymorphism in C5. Impact of the SNP on C5 functionality was assessed. Plasma C5a levels were significantly increased and C5 levels significantly lower with a higher copy number of the risk allele $(\mathrm{G})$ for rs17611, suggesting increased turnover of C5 V802.

The effect of C5 polymorphisms on the risk of stroke in Chinese patients has not been reported so far. Our research showed that the overall distribution of C5 rs17611 polymorphism was not associated with the risk of IS; however, when patients were divided into subtypes, we found a statistical difference between the LAA-subtype IS and C5 rs17611 gene polymorphisms in both GG genotype and G allele. Thus different genetic pathophysiological mechanisms seem to be associated with different stroke subtypes ${ }^{20}$. Our observations are partly in agreement with previous studies in Austrian stroke patients. Greisenegger, et al. found a statistically significant association between the C5 genotype and the risk of IS in Austrian participants ${ }^{6}$. Our study differed from the German population in which associations between the C5 gene polymorphism was not found to be significant in German participants ${ }^{21}$.

There are also some studies that prospectively investigated the effect of C5 rs17611 polymorphisms on stroke outcome. No association was observed between C5 rs17611 and six-month mortality after intracerebral hemorrhage ${ }^{22}$. However, Hoke et al. thought the C5 rs17611 GG genotype represented a risk factor for adverse cardiovascular outcome in male patients with carotid atherosclerosis ${ }^{23}$. They reached different conclusions in different disease outcomes. In our study, we also evaluated the impact of C5 rs17611 on the severity and outcome of acute IS, but found no association between the gene polymorphism and disease severity and outcome of IS and subtypes. The discordance in the findings may be explained by differences in ethnicity, genetic predisposition, methodology, and study design.

\section{Limitation}

Some limitations of this study should be pointed out. First, the conclusions only apply to Chinese people. However, because China is a populous country, the data derived from such large population can provide valuable reference for the studies of other ethnic groups in other countries. In addition, this study did not elucidate the relationship between C5 rs17611 gene function and the pathogenesis of LAA type ischemic stroke. Further studies are needed. We hope to find more genetic polymorphism interactions for genes with other functions to obtain further scientific results in future studies.

In summary, we investigated an association of IS occurrence and C5 rs17611 polymorphism. More interesting is that we found the GG variant contributing to the risk of LAA-subtype IS. However, we were unable to find an association between IS functional outcome at 90 days and C5 rs17611 variants. Nevertheless, this is the first evaluation of the association between C5 rs17611 genotypes and the occurrence, severity, and outcome of IS in Chinese patients. More evidence is needed to determine the validity of our findings through independent replication in more populations, to test the hypothesis that this genetic variation is, indeed, associated with occurrence of IS. Future studies should address the molecular mechanisms and how they target C5.

\section{References}

1. Cohen-Cory S, Kidane AH, Shirkey NJ, Marshak S. Brain-derived neurotrophic factor and the development of structural neuronal connectivity. Dev Neurobiol. 2010;70(5):271-88. doi:10.1002/dneu.20774

2. Ross R. Atherosclerosis: an inflammatory disease. N Engl J Med. 1999;340(2):115-26. doi:10.1056/NEJM199901143400207

3. Warlow C, Sudlow C, Dennis M, Wardlaw J, Sandercock P. Stroke. Lancet. 2003;362(9391):1211-24. doi:10.1016/S0140-6736(03)14544-8

4. Glass CK, Witztum JL. Atherosclerosis: the road ahead. Cell. 2001;104(4):503-16. doi:10.1016/S0092-8674(01)00238-0

5. Niculescu F, Rus H. The role of complement activation in atherosclerosis', Immunol Res. 2004;30(1):73-80. doi:10.1385/IR:30:1:073

6. Greisenegger S, Zehetmayer S, Bauer P, Endler G, Ferrari J, Lang $W$ et al. Polymorphisms in inflammatory genes and the risk of ischemic stroke and transient ischemic attack: results of a multilocus genotyping assay. Clin Chem. 2009;55(1):134-8. doi:10.1373/clinchem.2008.112151
Seifert PS, Hansson GK. Complement receptors and regulatory proteins in human atherosclerotic lesions. Arteriosclerosis. 1989;9(6):802-11. doi:10.1161/01.ATV.9.6.802

8. Széplaki G, Varga L, Füst G, Prohászka Z. Role of complement in the pathomechanism of atherosclerotic vascular diseases. Mol Immunol. 2009;46(14):2784-93. doi:10.1016/j.molimm.2009.04.028

9. Stokowska A, Olsson S, Holmegaard L, Jood K, Blomstrand C, Jern $\mathrm{C}$ et al. Plasma C3 and C3a levels in cryptogenic and large-vessel disease stroke: associations with outcome. Cerebrovasc Dis. 2011;32(2):114-22. doi:10.1159/000328238

10. Mocco J, Wilson DA, Komotar RJ, Sughrue ME, Coates K, Sacco RL et al. Alterations in plasma complement levels after human ischemic stroke. Neurosurgery. 2006;59(1):28-33. doi:10.1227/01.NEU.0000219221.14280.65

11. Széplaki G, Szegedi R, Hirschberg K, Gombos T, Varga L, Karadi I et al. Strong complement activation after acute ischemic stroke is associated with unfavorable outcomes. Atherosclerosis. 2009;204(1):315-20. doi:10.1016/j.atherosclerosis.2008.07.044 
12. Hillebrandt S, Wasmuth HE, Weiskirchen R, Hellerbrand C, Keppeler $H$, Werth A et al. Complement factor 5 is a quantitative trait gene that modifies liver fibrogenesis in mice and humans. Nat Genet. 2005;37(8):835-43. doi:10.1038/ng1599

13. Liu B, Wei L, Meyerle C, Tuo J, Sen HN, Li Z et al. Complement component C5a promotes expression of IL-22 and IL-17 from human T cells and its implication in age-related macular degeneration. J Transl Med. 2011;9(1):1-12. doi:10.1186/1479-5876-9-111

14. Woehrl B, Brouwer MC, Murr C, Heckenberg SG, Baas F, Pfister HW et al. Complement component 5 contributes to poor disease outcome in humans and mice with pneumococcal meningitis. J Clin Invest. 2011;121(10):3943-53. doi:10.1172/JCI57522

15. Giles JL, Choy E, Berg C, Morgan BP, Harris CL. Functional analysis of a complement polymorphism (rs17611) associated with rheumatoid arthritis. J Immunol. 2015;194(7):3029-34. doi:10.4049/jimmunol.1402956

16. Traylor M, Farrall M, Holliday EG, Sudlow C, Hopewell JC, Cheng YC. Genetic risk factors for ischaemic stroke and its subtypes (the Metastroke collaboration): a meta-analysis of genomewide association studies. Lancet Neurol. 2012;11(11): 951-62. doi:10.1016/S1474-4422(12)70234-X

17. Berger K, Stögbauer F, Stoll M, Wellmann J, Huge A, Cheng S et al. The glu298asp polymorphism in the nitric oxide synthase 3 gene is associated with the risk of ischemic stroke in two large independent case-control studies. Hum Genet. 2007;121(2):169-78. doi:10.1007/s00439-006-0302-2

18. Appelboom G, Piazza M, Hwang BY, Bruce S, Smith S, Bratt A et al. Complement Factor $\mathrm{HY} 402 \mathrm{H}$ polymorphism is associated with an increased risk of mortality after intracerebral hemorrhage. J Clin Neurosci. 2011;18(11):1439-43. doi:10.1016/j.jocn.2011.04.001

19. Hoke M, Speidl W, Schillinger M, Minar E, Zehetmayer S, Schönherr $M$ et al. Polymorphism of the complement 5 gene and cardiovascular outcome in patients with atherosclerosis. Eur J Clin Invest. 2012;42(9):921-6. doi:10.1111/j.1365-2362.2012.02669.x

20. Adams HP Jr, Zoppo G, Alberts MJ, Bhatt DL, Brass L, Furlan A. Guidelines for the early management of adults with ischemic stroke: a guideline from the American Heart Association/American Stroke Association Stroke Council, Clinical Cardiology Council, Cardiovascular Radiology and Intervention Council, and the Atherosclerotic Peripheral Vascular Disease and Quality of Care Outcomes in Research Interdisciplinary Working Groups: The American Academy of Neurology affirms the value of this guideline as an educational tool for neurologists. Circulation. 2007;115(20): e478-534. doi:10.1161/CIRCULATIONAHA.107.181486

21. Adams HPJr, Bendixen BH, Kappelle LJ, Biller J, Love BB, Gordon $\mathrm{DL}$ et al. Classification of subtype of acute ischemic stroke: definitions for use in a multicenter clinical trial. TOAST. Trial of Org 10172 in Acute Stroke Treatment. Stroke. 1993;24(1):35-41. doi:10.1161/01.STR.24.1.35

22. Meyer BC, Hemmen TM, Jackson CM, Lyden PD. Modified National Institutes of Health Stroke Scale for use in stroke clinical trials: prospective reliability and validity. Stroke. 2002;33(5):1261-6. doi:10.1161/01.STR.0000015625.87603.A7

23. Quinn TJ, McArthur K, Dawson J, Walters MR, Lees KR. Reliability of structured modified rankin scale assessment. Stroke. 2010;41(12):e602. doi:10.1161/STROKEAHA.110.590547 